\title{
Nature of Damage and Infestation of Dominant Foliage Herbivore of Soybean at Jimma-Iluababora, Ethiopia
}

\author{
Sisay Kidanu \\ Ethiopian Institute of Agricultural Research, Jimma Research Center, P. O. Box 192, Jimma, Ethiopia
}

\begin{abstract}
Leaf herbivore insects are among the most serious pests of soybean in Ethiopia. A survey was conducted on 90 farms in three main soybean growing districts in Jimma and Iluababora zones of Ethiopia. The objectives were to assess the socio demographic information of the farmers, to identify farmers' pest management practices and to study the importance and infestation of dominant leaf herbivore insect pests of soybean. The statistical analysis showed there is highly significant $(\mathrm{p}<0001)$ difference among studied districts in area coverage of soybean production and the majority of the farmers $(81.1 \%)$ produce soybean below a hectare. Farmers were using different pest management methods to reduce damage caused by leaf phaga insect pests which concentrated on cultural method. Crop rotation was one of the main farming systems practiced by $80 \%$ at Tiroafeta and 96.7 and $100 \%$ at Chewaka and Darimu districts. About $16.7 \%$ farmers of Tiroafeta were not practiced any management practices for pest management where as only $3.3 \%$ of them practiced manually hand picking method at Chewaka. At Darimu district, all surveyed farmers did not get any access to crop protection training, but at Tiroafeta and Chewaka only $3.3 \%$ of them got training opportunity provided by research center. The study revealed that the mean infestation level of green clover worm was $29.8 \%$ at Tiroafeta district and 47 and $50.4 \%$ at Chewaka and Darimu. The mean infestation of soybean semilooper was $25.3 \%$ at Tiroafeta and 14.6 and $15.6 \%$ at Chewaka and Darimu districts. The study showed that infestation of soybean leaf roller ranged from 2.5 to $8.2 \%$ in Jimma zone and up to $74 \%$ in Iluababora. Generally, these insect pests, needs due attention conducting regular scouting in unaddressed areas are very important for integrated pest management.
\end{abstract}

Keywords: Green cloverworm, infestation, leaf roller, semi-looper, soybean

DOI: $10.7176 / \mathrm{JEES} / 10-7-02$

Publication date:July $31^{\text {st }} 2020$

\section{Introduction}

Soybean (Glycine max L.) is one of the most important crop which is grown for oil and protein in the world (Biswas, 2013). It is an important among grain legumes for its economic benefits and is the major industrial and food crop grown in every continent. Seeds of soybean are used as food for humans, feed for animals and raw materials for industries grown. The seed contain about $42 \%$ protein and $20 \%$ oil and provide $60 \%$ of the world supply of vegetable protein and $30 \%$ of the edible oil (Fehr 1989). Soybean contributes to soil fertility improvement by symbiotic nitrogen fixation. Its oil is the largest component of the world's edible oils and it is also used as the ingredient for more than 50\% of the world's high protein meal (Jayanthi et al. 1993).

Ethiopia has favorable climatic and soil conditions for soybean production and grows well in several parts of the country, which includes: Jimma, Bedele, Chewaka, Assossa Pawe, Harar, Shashemene, and Arsi areas (Wijnands et al., 2011). In general, the low to mid altitude maize production areas of the country are believed to be suitable for soybean production (Tadesse and Sentayehu, 2015). In Ethiopia, soybean has increasing trends in production and productivity over the last decade. A total of 38,072.7 hectare of land were covered by soybean (CSA, 2017) and ranks first in yield per hectare among pulse and oil and 5th in area coverage among oil crops grown in the country. In the year 2017 the national average productivity of soybean was $2.27 \mathrm{t} / \mathrm{ha}$ (CSA, 2017), which was not close to the potential productivity of the crop, compared to its potential productivity in the research fields, which reach up to 3 t/ha (Abush, 2012).

Research in soybean has started about 50 years ago in Ethiopia. Currently, soybean is one of the focus subsectors supported by government and non-governmental organization. In the recent years several soybean processing plants have been set up in different parts of the country, which began demanding varieties with high grain nutritional compositions like oil and protein (Yechalew, 2018). Soybean production in Ethiopia is very far below its productivity compared to world average. This low productivity was because of number of factors and the main one is due to biotic. One of the major constraints to the successful soybean production is the damage caused due to insect pests (Biswas, 2013). Research experiences in Bangladesh revealed that 15 - 20 percent of the total soybean production is lost directly or indirectly by the attack of insect pests every year (Biswas 2008). In order to evolve economically feasible, ecologically sound pest management strategies, detailed information on the major pest status and damage level are of great importance. Therefore, the présent study was conducted to assess the status, infestation level and importance of major leaf damaging insect pests in some soybean producing areas. 


\section{Materials and Methods}

\subsection{Description of the study areas}

Chewaka resettlement area is located in Illubabor zone, Oromia regional state about 570 kilometers Southwest of the capital, Addis Ababa. It is situated in lowland areas of Dhidhessa valley, which lies below $1500 \mathrm{~m}$ above sea level. The area is found between Dabena and Dhidhessa rivers. The area experiences defined wet and dry seasons. The wet season is between May and October during which high precipitation is recorded. The maximum mean monthly precipitation is in June and July i.e. $275.28 \mathrm{~mm}$ and $292.8 \mathrm{~mm}$ respectively. The dry season lasts from November to April, which is marked by high temperature. The minimum and maximum temperature of the area is 14.76 and $30.99^{\circ} \mathrm{C}$ (Berhanu, 2007). Darimu district lies at $035^{\circ} 15$ to $035^{\circ} 32 \mathrm{E}$ longitudes and $08^{\circ} 30$ to $08^{\circ} 44$ latitude $\mathrm{N}$ of equator. The area of the district is $1387.97 \mathrm{sq} . \mathrm{km}$ and the altitude ranges from 1200 to 1800 m.a.s.l. The agro climatic situation is mid high land $53.5 \%$ and low land $46.6 \%$. Meteorology station recorded two season in the area, long rainy ( June - September ) with mean annual rain fall of $1456 \mathrm{~mm}$ and November-march long dry season, and with mean lower temperature $18^{\circ} \mathrm{C}$ and the highest average $25^{\circ} \mathrm{C}$. Most people in the area engaged in crop and livestock production (Teferi and Biniam, 2018). Tiro Afeta district is located in Jimma zone about 320 $\mathrm{km}$, to the Southwest of the capital city Addis Ababa. The altitude of Tiroafeta district ranges from 1340 to 2800 $\mathrm{m}$ a.s.l. The mean annual rainfall ranges between 1200 and $2800 \mathrm{~mm}$ with a mean temperature of $20-25^{\circ} \mathrm{C}$. The district, the most widely cultivated subsistence crops and some production of vegetable crops is observed in these areas (Adeba, 2016).

\subsection{Assessment of dominant leaf feeding insect pests \\ 2.2.1. Sampling procedures}

Three stages of sampling procedures were used to select farms and respondents. In the first stage, three major soybean producing zones were selected purposively based on soybean production potentials (Jimma and Iluababora zones). In the second stage, sample districts were selected purposively based on soybean production potentials based on the secondary data (Agricultural office or research centers). Maximum care was, therefore, taken to assess potential production areas, though we were constrained by time of the survey. From Jimma zone (Tiro afeta district) and from Iluababora zones (Darimu and Chewaka districts) were selected, by considering slightly more representation for the Jimma and Iluababora zones as the vast majority of soybean comes from there. In the third stage, from each districts three kebeles were selected and ten households were selected from each kebeles randomly. Systematic random sampling procedures were used in the farm. In each farm, $1 \mathrm{mx} 1 \mathrm{~m}$ quadrant was used to sample representatives' larva in the farms randomly from different sampled sites which were spaced at least 10 to $20 \mathrm{~m}$ apart. Sampling of flier insects was carried out using sweeping net and jar for preservation. Abundance and percent of infestation of the insect pests for each farm was calculated by averaging the records from fields within different farms. The same procedure was followed to determine abundance and percent of infestation for different soybean agro-ecology. The farms were situated within 3 to $7 \mathrm{~km}$ of each other depending on soybean farm availability. The assessment areas were categorized in to two altitudinal groups, Lowland 5001500; Midland 1500-2300 metres above sea level (Dereje and Eshetu, 2012). Semi-structured questionnaire was used during the survey to gather information about demographic characteristics of the respondents, agronomic practices and management practices for insect pests of the owner of the farm or his family in his absence.

\subsection{Data collected}

Socio-demographic, agronomic practices and pest management practices data as well as number of insects and their infestation on soybean plant was counted from each sample area and the percentage calculated to get the insect infestation. Phenology of the crop is based on standard growth stage as outlined by Iowa State University (Table 1). 
Table 1. Reproductive growth stages of a soybean plant

\begin{tabular}{|c|c|}
\hline Plant stages & Description \\
\hline Beginning bloom & One open flower at any node on the main stem \\
\hline Full bloom & $\begin{array}{l}\text { Open flower at one of the two uppermost nodes on the main stem with a fully } \\
\text { developed leaf }\end{array}$ \\
\hline Beginning pod & $\begin{array}{l}\text { Pod } 3 / 16 \text { inch long at one of the four uppermost nodes on the main stem with a fully } \\
\text { developed leaf }\end{array}$ \\
\hline Full pod & $\begin{array}{l}\text { Pod } 3 / 4 \text { inch long at one of the four uppermost nodes on the main stem with a fully } \\
\text { developed leaf }\end{array}$ \\
\hline Beginning seed & $\begin{array}{l}\text { Seed } 1 / 8 \text { long in a pod at one of the four uppermost nodes on the main stem with a } \\
\text { fully developed leaf }\end{array}$ \\
\hline Full seed & $\begin{array}{l}\text { Pod containing a green seed. Seed that fills the pod cavity at one of the four uppermost } \\
\text { nodes on the main stem with a fully developed leaf }\end{array}$ \\
\hline Beginning maturity & One normal pod on the main stem that has reached its mature pod colour. \\
\hline Full maturity & $\begin{array}{l}\text { Ninety-five percent of the pods that have reached their mature pod colour. Five to ten } \\
\text { days of drying weather are required after before the soybeans have less than 15-percent } \\
\text { moisture }\end{array}$ \\
\hline
\end{tabular}

Total number of sampled leaves

\subsection{Data analysis}

Descriptive statistics and comparative statistical tools including chi square were used to compare the different socio-demographic and farm characteristics on soybean leaf herbivore insect pests and pest management practices of farmers across the surveyed districts. The assessment data was analyzed using Statistical Package for Social Science (SPSS) version 20.0 .

\section{Result and Discussion}

\subsection{Socio-economic characteristics}

Among the interviewed farmers, $86.7 \%$ of them produce soybean from less than a hectare and only $13.3 \%$ is above a hectare at Tiroafeta in Jimma zone. In Iluababora zone, about $43.3 \%$ of Chewaka district farmers produce from greater than one hectare but all interviewed farmers from Darimu district produce soybean from less than a hectare. The statistical analysis showed there is highly significant $(p<0001)$ difference among studied districts in area coverage of soybean production and the majority of the farmers $(81.1 \%)$ produce soybean below a hectare (Table 2)

The analysis also indicated significant variation among studied districts practicing crop rotation and about $46.7 \%$ of the previous crop in the assessed farm was maize and followed by sorghum (30\%) and teff $(13.3 \%)$ crops at Tiroafeta district respectively. On the other hand, at Chewaka and Darimu sorghum was primarily planted by 46.7 and $40 \%$ farmers and followed by maize and teff (Table 2). Only few farmers (3.3\%) plant soybean after soybean, this implies that most farmers well understood the advantage of soybean to improve fertility of the soil. Soybean production at Jimma and Ilu-Ababora zone is still low, even though there is encouraging trend in the last few years.

Table 2. Socio-economic characteristics of the respondent farmers during the study ( $\mathrm{n}=90)$

\begin{tabular}{|c|c|c|c|c|c|}
\hline \multirow[t]{2}{*}{ Variables } & \multicolumn{4}{|c|}{ Districts } & \multirow[t]{2}{*}{$\chi^{2}$} \\
\hline & Tiroafeta & Chewaka & Darimu & Districts mean & \\
\hline Soybean farm area (ha) & & & & & $19.29 * * *$ \\
\hline Less than a hectare & 86.7 & 56.7 & 100 & 81.1 & \\
\hline Between 1-3hectare & 13.3 & 43.3 & 0.0 & 18.9 & \\
\hline Previous planted crop & & & & & $24.30 *$ \\
\hline Maize & 46.7 & 20.0 & 33.3 & 33.3 & \\
\hline Sorghum & 30.0 & 46.7 & 40.0 & 38.9 & \\
\hline Soybean & 10.0 & 0.0 & 0.0 & 3.3 & \\
\hline Teff & 13.3 & 13.3 & 26.7 & 17.8 & \\
\hline Millet & 0.0 & 3.3 & 0.0 & 1.1 & \\
\hline Rice & 0.0 & 6.7 & 0.0 & 2.2 & \\
\hline
\end{tabular}

Statistically significant $*$ at $\mathrm{p}<0.05$, highly signi $* * \mathrm{p}<0.01, * * * \mathrm{p}<0.001 ; \mathrm{NS}=$ not significant, $\chi 2$ chi-square

Among the assessed soybean farms, the majority were at the beginning of pod setting stage (76.7\%) during the survey, this was also the case in all surveyed districts. About $26.7 \%$ of the assessed farms crop phenology was 
at full blooming during the study both at Tiroafeta of Jimma and Darimu of Iluababora zone. Anonymous (2019) reported that leaf feeders such as green cloverworm and loopers are common insect pests' results serious damage from early flowering to early pod fill and at mid to late pod-fill stages in Tennessee. The survey was conducted in different agroecologies. About $93.3 \%$ of the assessed farms at Chewaka district were under lowland (between 500 - 1500 masl) category where as at Tiroafeta and Darimu all the assessed farms were under midland (between 15002300 masl). This showed that soybean in the country is produced from different altitudinal range below 2300 masl (Table 3).

Table 3. Crop phenology and agroecology of the farmers soybean farm during the study $(\mathrm{n}=90)$

\begin{tabular}{|c|c|c|c|c|c|}
\hline \multirow[b]{2}{*}{ Variables } & \multicolumn{4}{|c|}{ Districts } & \multirow[b]{2}{*}{$\chi^{2}$} \\
\hline & Tiroafeta & Chewaka & Darimu & Districts mean & \\
\hline Crop stage during study & & & & & $14.03 *$ \\
\hline Beginning of bloom & 0.0 & 6.7 & 0.0 & 2.2 & \\
\hline Full bloom & 26.7 & 3.3 & 26.7 & 18.9 & \\
\hline Beginning of pod-set & 73.3 & 83.3 & 73.3 & 76.7 & \\
\hline Beginning of maturity & 0.0 & 6.7 & 0.0 & 2.2 & \\
\hline Agro-ecology covered & & & & & $81.29 * * *$ \\
\hline Lowland & 0.0 & 93.3 & 0.0 & 31.1 & \\
\hline Midland & 100 & 6.7 & 100 & 68.9 & \\
\hline
\end{tabular}

Statistically significant $*$ at $\mathrm{p}<0.05$, highly sign $* * \mathrm{p}<0.01,{ }^{* * *} \mathrm{p}<0.001 ; \mathrm{NS}=$ not significant, $\chi 2$ chi-square

Except a few, almost all farmers $(86.7 \%)$ of the surveyed soybean farmers in Tiroafeta district use fertilizer for soybean production, whereas, few farmers (13.3\%) use in Darimu district. However, in Chewaka district only $3.3 \%$ of the farmers use fertilizer for soybean (Fig. 1 ); this was because the soil is very fertile and may be due to Tiroafeta district is near to research center than the other hence better access to soybean improved technology. On the other hand, farmers of different districts were using cultural method and farming system to reduce the damage inflicted by the leaf herbivore insects. Crop rotation was one the main farming system practiced by $80 \%$ at Tiroafeta and 96.7 and $100 \%$ farmers at Chewaka and Darimu districts respectively (Fig. 2). On the other hand, $16.7 \%$ farmers of Tiroafeta were not practiced any management practices where as only $3.3 \%$ of farmers were practiced manually insect hand picking method at Chewaka. At Darimu district, all surveyed farmers did not get any access to crop protection training, but at Tiroafeta and Chewaka only $3.3 \%$ of them got training opportunity provided by research center (Fig.3).

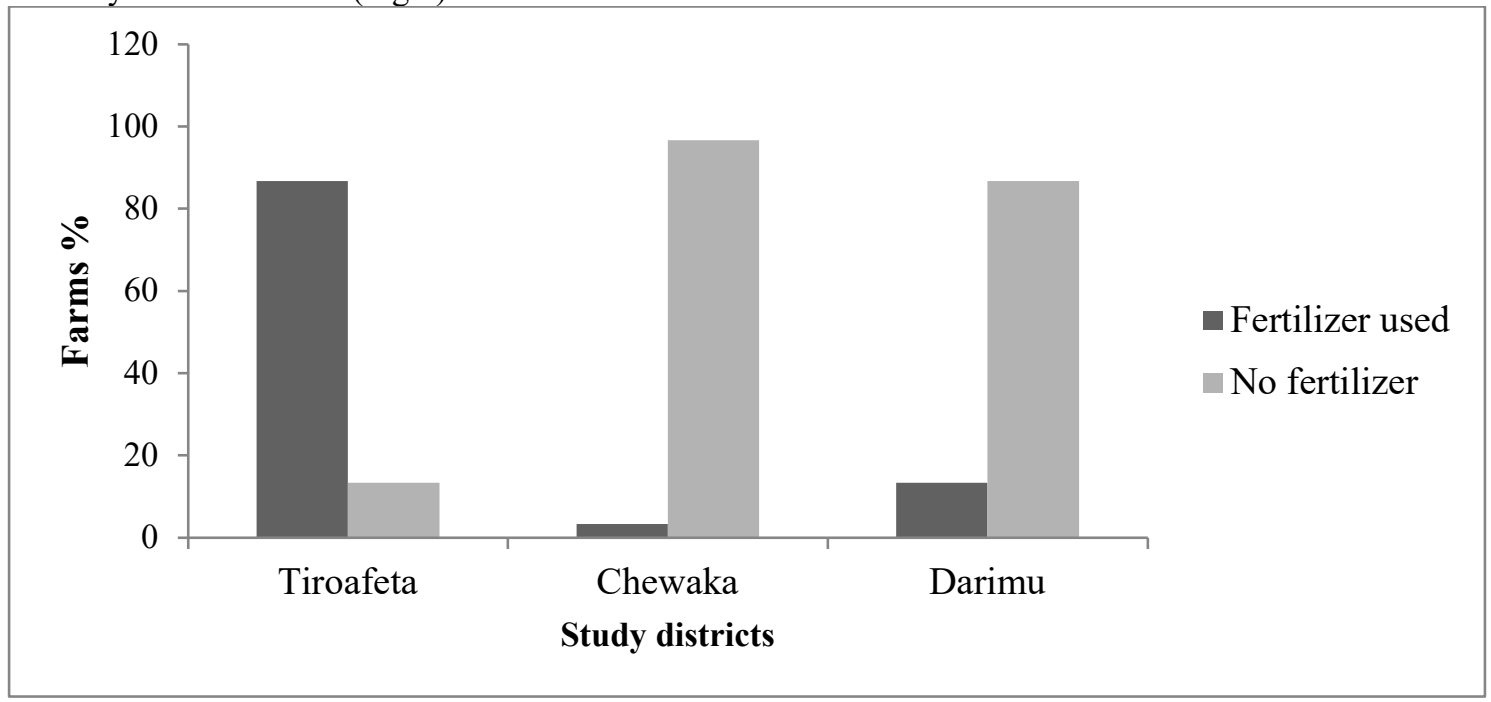

Fig. 1. Fertilizer used by farmers for soybean production in studied districts 




Fig. 2. Farmers practices for leaf damaging insect pests of soybean management

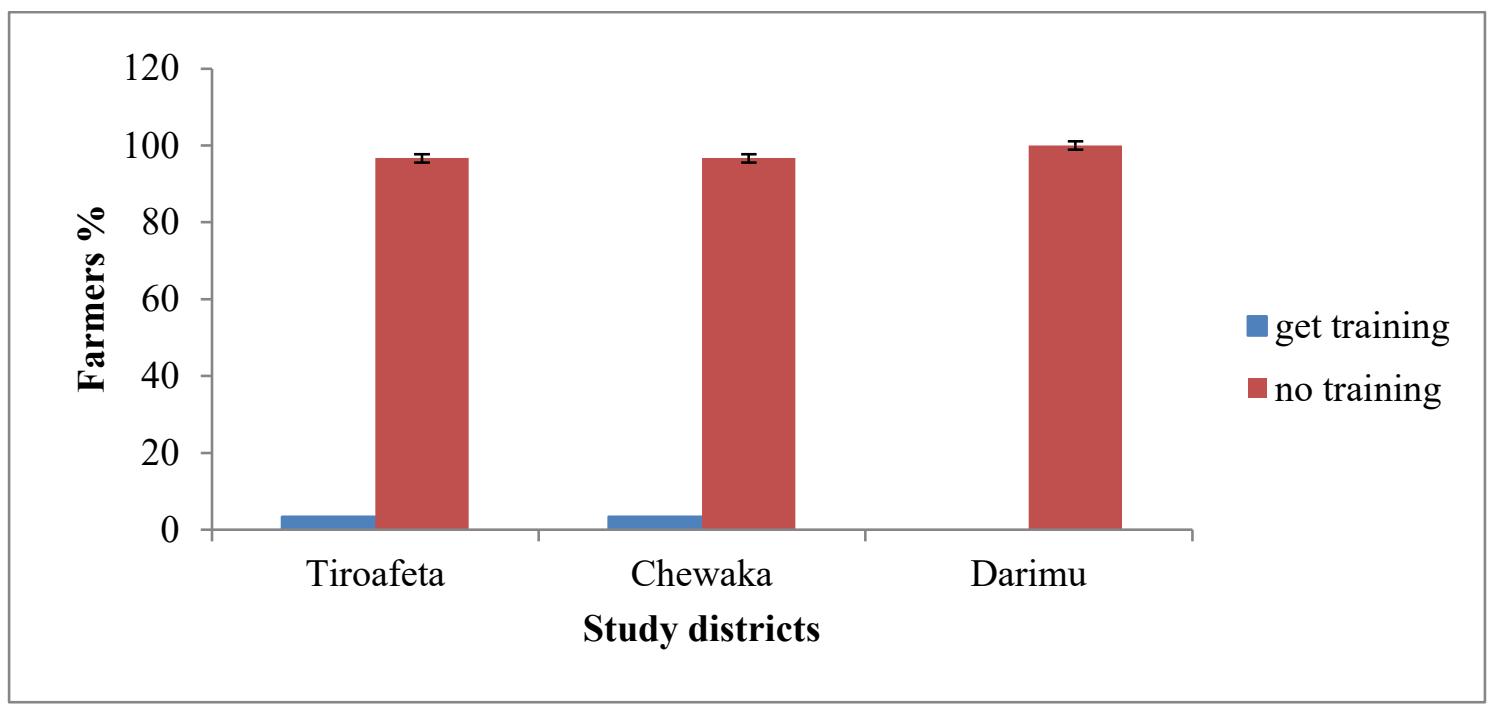

Fig. 3. Soybean farmers access to crop protection training

\subsection{The importance and infestation of the dominant leaf herbivores}

Different insect pests were observed on soybean field during the survey conducted in the main cropping season. Some are detrimental, while others may beneficial. The study was focused on the three most dominantly observed soybean leaf herbivore insect pests which may cause serious damage and yield reduction if an outbreak occurs and not controlled. Green cloverworm (Plathypena scabra) a Lepidoptera, Noctuidae is a moth which its larvae is slender green caterpillar with three pairs of abdominal prologs, feed extensively on soybean leaves (Fig.4A). However, it is generally of minor importance because of the soybean plants ability to compensate for foliage losses. The study revealed that the infestation was ranged from 0.0 to $87.5 \%$ in Jimma zone and up to $100 \%$ at Ilu ababora (Table 4). This infestation of green clover worm may be varying from season to season and the mean infestation of this leaf herbivore insect was $29.8 \%$ at Tiroafeta district and 47.0 and $50.4 \%$ at Chewaka and Darimu respectively (Fig.6).

Green cloverworm becomes very active and falls to the ground when disturbed. The feeding damage produced is similar to that of loopers. Although they are present most of the growing season, they are damaging only at high populations or in combination with other defoliators (Anonymous, 2019).

On the other hand, Soybean semilooper (Plusia orichalcea Fab a Lepidoptera, Noctuidae its larvae was light green and have two pair of abdominal prologs (excluding the pair on the last abdominal segment (Fig.4B). It frequently feed which cause the plant leaves with a ragged appearance and is capable of inflicting heavy foliage losses and pod damage. From this study different infestation level of semilooper was recorded at the studied districts. In Jimma zone up to $64.5 \%$ of infestation of soybean semilooper where as in Ilu ababora, up to $95 \%$ was recorded during the assessment (Table 4). The mean infestation was $25.3 \%$ at Tiroafeta and 14.6 and $15.6 \%$ at Chewaka and Darimu districts respectively (Fig. 6). 
According to Tsedeke et al (1982) soybean semilooper has a variety of hosts in Ethiopia which includes soybean (frequently recorded from Debrezeit and Jimma), haricot bean and cowpea. This insect was fairly common at Jima but large numbers of larvae migrate from Guizotia scabra, a weed to soybean fields. Anonymous (2019) reported that soybean loopers are often the common worms in soybean which form the characteristic hump or loop when crawling and when the population become heavy, they eat much of the leaf surface, causing the plant very ragged (Fig. 4B). The author also stated that populations are often held in check by beneficial insects and diseases. Defoliating Pests (bean leaf beetles green cloverworm, blister beetles, loopers, Treat at 30 percent defoliation until bloom, 20 percent from bloom to full seed and 30 percent after full seed plus 7-10 days. Alternatives to defoliation thresholds during pod filling, green cloverworm is 38 larvae per 25 sweeps and loopers is 19 larvae per 25 sweeps. Although many pyrethroid insecticides are labeled for soybean looper control, they are not recommended because resistance is well documented.
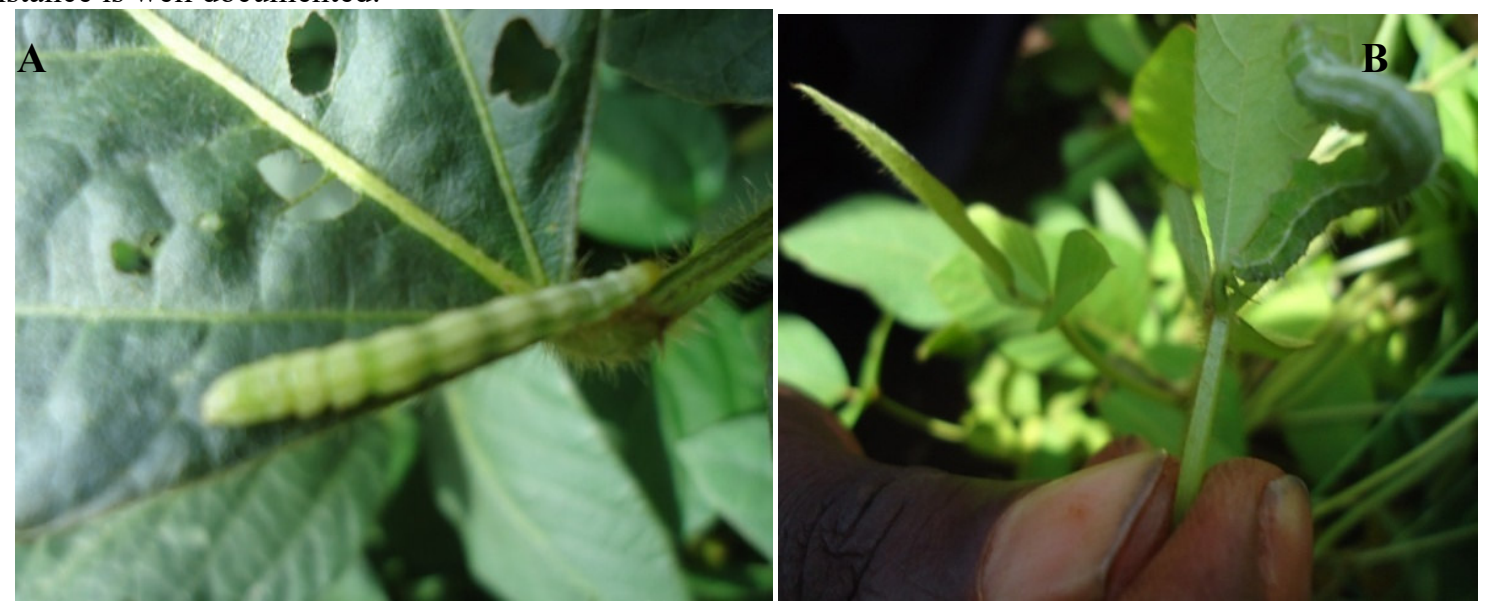

Fig. 4. Green cloverworm larvae (A) feeding soybean leaf and Semilooper larvae (B) feeding the leaf (Photo: Sisay)

Soybean leaf roller (Lamprosema indica F.) a Lepidoptera, Noctuidae also known leaf webworm or folder, is a moth caterpillar observed feeding on leaves after spun together, causing a characteristics windowing as the upper epidermis of leaves remains untouched (Fig.5). The assessment study showed that infestation of soybean leaf roller ranged from 2.5 to $8.2 \%$ in Jimma zone and up to $74 \%$ in Iluababora (Table 4). At Tiroafeta district mean infestation of $3.11 \%$ recorded and 4.3 and $4.4 \%$ were recorded at Chewaka and Darimu district respectively (Fig. 6). These randomly observed insect pests might be important in the future when they get conducive environmental condition. However the yield level was not affected much because these insects are generally of minor importance because of the soybean plant's ability to compensate for foliage losses (Doug, 2010).

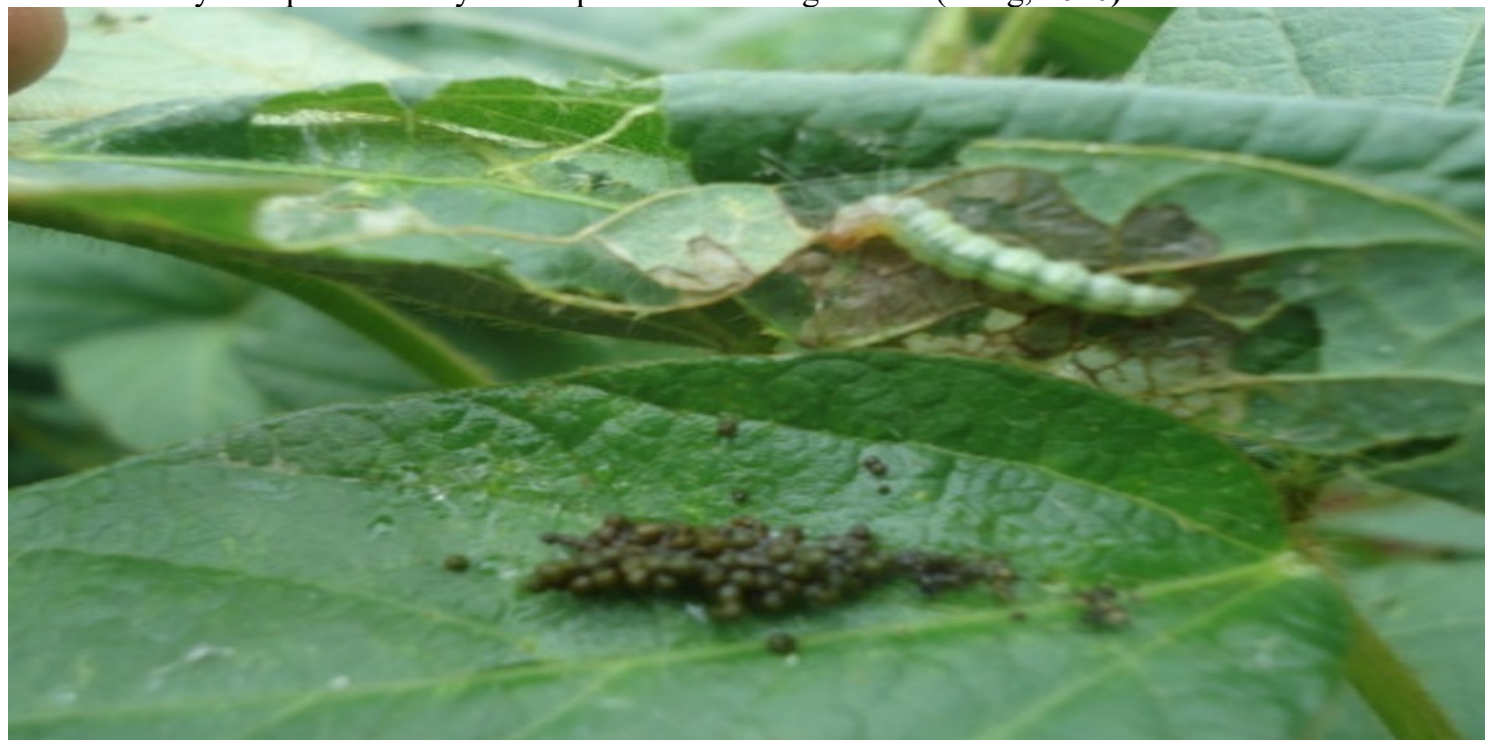

Fig. 5. Soybean leaf roller larvae feeding soybean leaf in Tiroafeta of Jimma (Photo: Sisay) 
Table 4. Soybean major leaf feeder's infestation and other relevant geographical data of the surveyed districts in Jimma and Ilu-Ababora zones.

\begin{tabular}{|c|c|c|c|}
\hline \multirow[b]{2}{*}{ Variables } & \multirow{2}{*}{$\frac{\text { Jimma }}{\text { Tiro Afeta }}$} & \multicolumn{2}{|c|}{ Iluababora } \\
\hline & & Chewaka & Darimu \\
\hline Latitude(N) & $07^{0} 51.34-07^{0} 58.50$ & $08^{0} \quad 46.32-09^{0} \quad 0.08$ & $08^{0} \quad 33.42-08^{0} \quad 36.83$ \\
\hline Longitude(E) & $37^{0} \quad 11.97-37^{0} \quad 18.17$ & $\begin{array}{llll}36^{0} & 06.59 & -36^{0} & 12.11\end{array}$ & $35^{0} 26.95-35^{0} 37.41$ \\
\hline Altitude ( $\mathrm{m}$ as 1$)$ & $1715-1950$ & $1223-1690$ & $1638-1772$ \\
\hline Leaf feeder studied & & Infestation (\%) & \\
\hline Green clover worm & $0.0-87.5$ & $0.0-100$ & $0.0-100$ \\
\hline Soybean semi-looper & $0.0-64.5$ & $0.0-83.3$ & $0.0-95.0$ \\
\hline Soybean leaf roller & $2.5-8.2$ & $0.0-11.5$ & $0.0-74.0$ \\
\hline
\end{tabular}

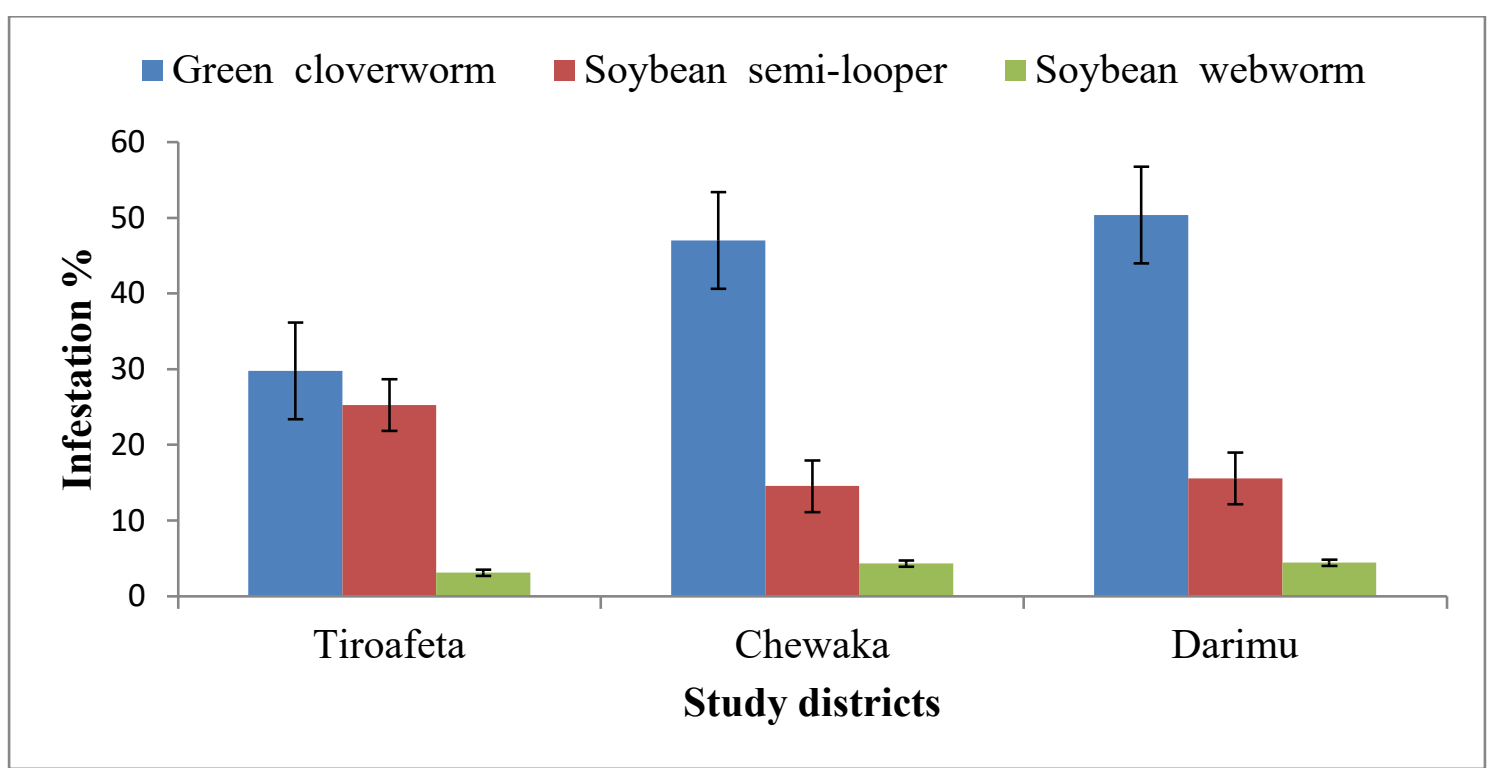

Fig. 6. Mean infestation of dominant soybean leaf herbivores in Jimma and Iluabora zones

In most places the performance of soybean is high at those districts due to the fertility of the area and warm climate that favored the crop. Generally, these insect pests, especially, green clover worm needs due attention during variety evaluation and release of soybean. On the other hand, soybean leaf roller (leaf folder) larvae was recorded in the Jimma area spinning webs and folding soybean leaf and was a very important pest, causing serious damage (Tsedeke et al., 1982).

\section{Conclusion}

Currently, green clover worm, soybean semilooper and Soybean leaf roller are the three dominantly recorded insect pests in the Jimma area soybean producing districts. However, the level of infestation varies from year to year as we gathered information from farmers. An integrated pest management (IPM) program is very important which integrates control tactics including cultural practices, variety selection, biological control and insecticides to manage insect pest populations so that economic damage and harmful environmental side effects are minimized. Insecticides should only be used on an as-needed basis; therefore, insect scouting must be conducted regularly throughout the season to determine if an insecticide application is warranted. In general, awareness creation about the dominant insect pests for district and zone ministry of Agriculture staff through training is needed because little attention is given for the pests. Planting on time and natural enemies will keep these insect pests from becoming a problem. These insect pests which were observed in the surveyed fields, should get due attention, because they may cause high infestation for the future when they get conducive conditions.

\section{Acknowledgements}

My thanks go to Ethiopian Institute of Agricultural Research (EIAR), Jimma Agricultural Research Center (JARC) for their provision of logistics and vehicle during our survey work. I'm grateful also to JARC pulse and oilseed research team, Agronomy and protection experts of Tiroafeta, Chewaka and Darimu districts for their help they made during the study. 


\section{Reference}

Abush, T., 2012. Genetic analysis of quantitative traits in Soybean (Glycine max L. Merril) under low and high phosphorus conditions. Ph.D Thesis. University of KwaZulu-Natal, Pietermaritzburg. South Africa.184pp.

Adeba, G., 2016. Estimation of Soil Loss Using Revised Universal Soil Loss Equation and Determinants of Soil Loss in Tiro Afeta and Dedo Districts of Jimma Zone, Oromiya National Regional State, Ethiopia. Trends in Agricultural Economics, 9: 1-12.

Anonymous, 2019. Soybean Insect Control Recommendations in Tennessee, pp. 17-19.

Berhanu, G.M., 2007. The Impact of Resettlement On Woodland Vegetation: The Case of Chewaka Resettlement Area, Southwestern Ethiopia, MSc Thesis, Addis Ababa University, Addis Ababa, Ethiopia pp 24-25.

Biswas, G.C., 2013. Insect pests of soybean (Glycine max L.), their nature of damage and succession with the crop stages. Journal Asiat. Soc. Bangladesh, Sci. 39(1): 1-8.

Biswas, G.C., 2008. Insect pests and their management of soybean crop in Bangladesh. Proceedings of the Workshop on Prospects and Performance of Soybean in Bangladesh (M.A. Bakred.) ORC, BARI, Gazipur, pp.67.

CSA (Central Statistical Authority), 2017. Agricultural sample survey statistical volume 1. Bulletin no 586. Addis Ababa, Ethiopia, P 14.

Dereje, G. \& A. Eshetu, 2012. Crops and Agro-ecological Zones of Ethiopia.

Doug, J., 2010. Green cloverworm, Plathypena scabra (Lepidoptera: Noctuidae) in Kentucky soybean. University of Kentucky College of Agriculture

Fehr, W.R., 1989. Soybean, importance and distribution pp. 283-300. In: Robblen. G.R.K.Downy and Ashri (ed). Oilcrops of the world. Mc-Grow-Hill Pub. Com. New York.

Hans, K. 2010. Soybean Production Fargo, North Dakota. Pp5.

Jayanthi, M., K.M. Singh \& R.N. Singh, 1993. Pest complex of high yielding groundnut variety MH4 under Delhi comdition. Indian J. Ent., 55(1): 30-33.

Palle, P., 2007. Soybean Physiology: Yield, Maturity Groups and Growth Stages. Iowa State University, pp. 1-27.

Tadesse, G. \& A. Sentayehu, 2015. Genetic divergence analysis on some soybean (Glycine max L. Merrill) genotypes grown in Pawe, Ethiopia. American-Eurasian Journal. Agric. \& Environ. Sci.,15(10):1927-1933.

Teferi, B. \& T. Biniam, 2018. Study on Bovine Trypanosomosis and Tse Tse Fly Challenge in Darimu District of Birbir Valley, Southwestern Ethiopia. Journal of Veterinary Science and Research, 3(1):1-8.

Tsedeke, A., G.M. Tadesse \& A. Kemal, 1982. Arthropod pests of grain legumes in Ethiopia, their importance and distribution. Institute of agricultural research, Addis Ababa, Ethiopia, 63p.

Wijnands, J.H.M., N.D. Gurmesa, J.C.M. Lute \& E.N.Van Loo, 2011. Ethiopian soybean and sunflower value chains: Opportunities and challenge, 2011-016.

Yechalew, S., 2019. Estimation of Variability, Correlation and Path Analysis in Soybean (Glycine max (L.) Merr.) Genotypes at Jimma, South Western Ethiopia, Journal of Natural Sciences Research, 9(7): 22-29. 